\title{
The perspective of organic wine in Brazil - trends, demands and production
}

\author{
Marcos Vinícius Araujo ${ }^{a}$, Marielen Aline Costa da Silva, Daniela Callegaro de Menezes, and Kelly Lissandra Bruch \\ Center for Studies and Research in Agribusiness - CEPAN / Universidade Federal do Rio Grande do Sul - UFRGS, Av. Bento \\ Gonçalves, 7712 Porto Alegre, RS, Brazil
}

\begin{abstract}
This work aims to analyze the productive reality and propose a panorama for the Brazilian organic wine production, from the perspective of producers, representatives of the sector, market and consumers, thus seeking to highlight the market perspectives and adequacy to the consumers' aspirations. This production that aims to meet a growing demand for sustainable products, which include organic, biodynamic and natural foods, combined with the growing Brazilian tendency to consume better quality wines. To prosecute this study, an exploratory research was developed, interviewing twenty consumers, one intermediary, one representative of the sector and four wineries. The data were analyzed crossing the information collected with these actors and bring out key contents. The results show that production is not aligned with consumer demand that it is still necessary to review the information made available to consumers, in addition to making it clearer, other values could be aggregated to those products or better communicated. On this way, it is possible to conclude that an intermediate product between organic and conventional, which has sustainable practices in its production could meet the current demand, so that in the future it can produce an organic product that corresponds to the consumer's demand.
\end{abstract}

\section{Introduction}

From the sensible changes in the consumption habits of Brazilians, the emerging Brazilian economy and the great increase of the middle class [1], the Brazilian consumer started to buy products that had not consumed before due to the greater purchasing power [2], mainly fine and sparkling wine.

This change was perceived in several sectors, such as in the wine market and also organic products. In the Brazilian wine sector, there was a significant increase in the marketing of imported fine wines and national sparkling wines and decrease in table wines between 2010 and 2016, according to Chart 01 . The production of grape juice may be one of the causes of the decrease in marketing of table wine, which in Brazil are produced from the same grape variety - Vitis Rupestris, Vitis Labrusca and hybrids of vitis sp.

It is also important to note that in Brazil only fine wines produced from Vitis Vinifera varieties are imported. In Brazil, fine wine is seen as a more elitist product and consumed by a population with more income and education, while table wine is consumed by a smaller income parcel, presents characteristics of the varieties of grapes used and has more affordable prices [3].

In this sense, consumption of organic products is also increasing in developing countries [1]. These are consumers motivated by their environmental attitudes, which make them consume green products [4], such as organic foods. In Brazil, the organic production has grown more than $20 \%$ per year, but production still cannot meet

a e-mail: araujovmarcos@gmail .com the demand for these products, due, among other factors, to the quantity exported to Europe [5]. On the other hand, the trend in the consumption of organic wines still presents a challenge for the sector, which started in the production of organic grapes for wine processing in the 1990s.

These difficulties are resulting mainly by the climatic resistance of the vines, in particular the Vitis Vinifiera varieties. Due to the climate, these varieties are more susceptible to diseases and require more chemical interventions [6]. As an alternative to the traditional system, organics it combines traditional methods with modern agricultural practices, crop rotation, diversification, better land use, such as green and animal fertilization, and natural pest control [7].

These practices make organic wine is seen as safe, healthy and high-quality, yet only be sustainable is not enough to be consumed, the consumer of organic food have to like the taste of the product [8]. In this same perspective, it is important to emphasize that there is difference between organic, biodynamic and natural wines, which are often confused by consumers. If organic wine is restricted to the use of synthetic materials in production, biodynamic is an expression of terroir and climate, man only collaborates so that the roots of the plant reach to a depth that can best express characteristics of that ground and plant [9], some practices resemble homeopathy and follow the lunar calendar.

Natural wine, however, is not clearly defined and is a relatively modern term [10], but is regarded as a wine that uses ancient techniques to produce a wine without any additives, it is the pure expression of the grape, with no added water, sugar, tannins or any other [11], even the fermentation is done naturally. Thus, the main difference

(c) The Authors, published by EDP Sciences. This is an Open Access article distributed under the terms of the Creative Commons Attribution License 4.0 (http://creativecommons.org/licenses/by/4.0/). 


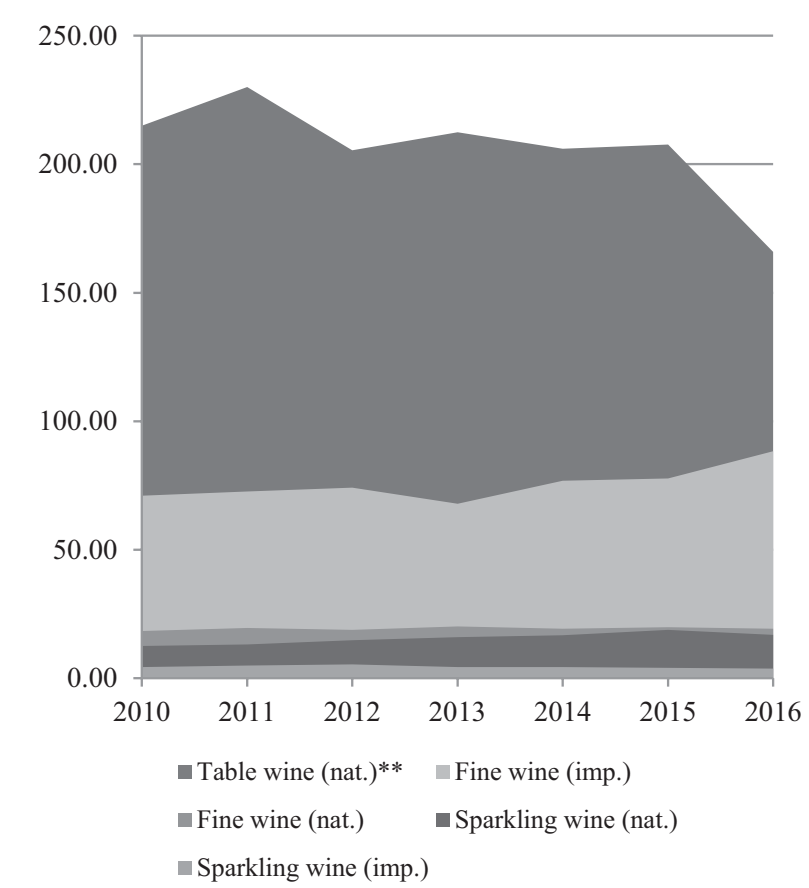

* From the production of the State of Rio Grande do Sul, representing $90 \%$ of the national production; ** Produced from Vitis Labrusca, Vitis Rupestris and hybrids of vitis $s p$.

Source: IBRAVIN-SISDECLARA, adapted by the author.

\section{Chart 01 - Comparison between commercialization of table wines and fine wines in Brazil*}

between these three products is that the natural does not use any additives for production, not even natural, it is a pure product. Biodynamic uses only natural processes and follows the lunar calendar and seeks expression of the plant and soil in the product, but uses natural additives. The organic is a production without the use of synthetic additives and with limited use of some additives in winemaking, such as sulfite.

In Brazil, organic wine is regulated by the organic system of agricultural production, subject to certification under Law 10,831, of 23 December 2003, and processes described in Joint Normative Instruction $\mathrm{n}^{\circ} 18$, of 28 May 2009 , for processed organic food. This product is certified by accredited organizations at the Brazilian Ministry of Agriculture, Livestock and Supply, which certifies minimum processes, as described above, thus ensuring a safe and reliable product to the consumer.

It is the characteristics of these practices, within the organic production system that attract consumers' attention. More specifically organic wine, these consumers are concerned about the health of the product, the environment and they seek more information, tend to buy in specialized stores, associate this category with a more expensive product, want to know the region produced, take into consideration the price, environmental aspects and the organic system, moreover, they feel like a sacrifice, not a pleasure, which may justify the segment still being small, besides not being willing to change the quality of the conventional wine for an ecological one [14]. The authors further conclude that the perception of genuine and modern flavor could be a strong argument for the product.

In the organic wine segment there is a subjectively perceived status in the consumption process of this product. In this sense, it is important to value the positive social image of organic wine, health effects, due to the absence of chemical residues, positive environmental effect, its origin, production system and wine color [15].

Attracted by traceability, concerned about the future of the planet and consuming products that are better for health, the search for organic wine increases in Europe, especially among the female and young people. In addition, they are informed consumers and the lack or unavailability of quality information can be a limitation in the search for this product [16]. In France, conventional wine consumption has not changed much in recent years, unlike organic wine, in 2013, one in three consumers consumed organic wine [17]. On the other hand, from 2015 to 2016 the growth was $10 \%$, in addition to the increase of 227 to 323 organic wine producers in the country, also having an increase of more than $10 \%$ in internal and external marketing, in the same period [18].

In Brazil, organic wine continues have little representation for the sector, which according to IBRAVIN Brazilian Wine Institute - may be linked to difficulties in organic grape production, due to climatic problems and adaptation of vines to the region's climate. Thus, what we have is the production of organic table wines, which go to the disagreement of the consumer's preference for organic wines.

Intended to meet a demand for healthier and ecologically correct products, associated with the market trend, which motivated the Brazilian wineries to convert to organic wine production. Given this scenario, in which the Brazilian organic wine industry is inserted, the difficulties, limitations and promising perspective of the sector, due to the demand of this market niche, this work aims to analyze the productive reality and propose a panorama for the organic wine production in Brazil, based on the vision of producers, representative of the sector, market and consumers, thus seeking to highlight the market prospects and adequacy to the consumers' wishes.

\section{Material and methods}

A qualitative exploratory research was developed since May 2015, and secondary data collection and interviews with wineries that produces wine and organic grape juice and they had a complete mix of products, such as table wines, grape juice, fine wines and sparkling wines. Four wineries were visited and interviewed between May 2015 and May 2016, in the cities of Bento Gonçalves (Winery 01 and 03), Garibaldi (Winery 02) and São Marcos (Winery 04), located in the State of Rio Grande do Sul, Southern Brazil. The wineries studied represents the most of Brazilian organic wine production.

Were conducted semi-structured interviews were conducted with: 01 (one) intermediary from São Paulo, which sells organic, natural wines and specializes in Brazilian wines, also conventional; 01 (one) representative of the productive sector belonging to IBRAVIN - Brazilian Wine Institute; and 19 (nineteen) consumers of organic foods, from the city of Porto Alegre and 01 (one) from São Paulo. Other secondary data was collected in articles from EMBRAPA (Brazilian Corporation of Agricultural Research), which dedicate research to the development of organic grape production. The interviews occurred first with the wineries, the intermediary, the wine sector, so that 
it could elucidate issues from the chain links to interview the consumers.

The interviewees were chosen for convenience, due to the difficulty in finding producers, marketers and consumers of this product, except the wine sector, which was chosen IBRAVIN for being the representative of the Brazilian wine sector. The intermediary was chosen because it is inserted on the dynamic of commercialization of Brazilian wines, also providing organic and natural wines and being close to consumers and producers.

Consumers were interviewed at ecological fairs in Porto Alegre, according to availability to respond to the interview. Other consumers were interviewed for participating in related organizations and indicated by other consumers of organic foods. The criteria of selection were whether consumed organic foods weekly, consumed wine or had consumed some type of organic wine previously.

The interviews were conducted in person and by videoconference, with a consumer from São Paulo and the audio recorded. In addition, secondary data were also collected from advertising materials from wineries, social networks, sites and in loco.

\section{Results and discussion}

The results were analyzed from the information crossreferencing, seeking to show which values consumers expect from organic wine, criteria in the wine buying moment and organic foods. Keywords were taken from the responses of the wineries, the market (intermediary) and the sector, which presented the questions about the product offer, for sampling the current Brazilian overview, following to the future outlooks of Brazilian organic wine, from the perspective of these three actors and consumers.

From the view of these actors, it separated into two topics. The first approach the current overview of Brazilian organic wine, and then seeks to understand the future outlooks of this product, based on the production and commercialization of the product, which includes the second topic.

\subsection{Current overview of organic wine}

The results show a production still in the process of development, with the production of organic grapes being the most sensitive part of the sector, since the more resistant varieties do not meet the type of product that is in increasing demand in Brazil. On the other hand, the industry is already moving to begin to meet these demands, seeking solutions, in addition to understanding that this is a growing niche market that demands attention. Table 1 presents a deeper understanding of the themes that emerged in interviews with wineries, intermediary of market and representative of sector, from productive realities, availability of information, marketing approaches and consumer profile.

It is possible to perceive that each winery approaches this production and market relation in a different way, starting from different interests. The wineries that understand this production as a market and positioning approach the product more broadly, within their communication and with specific advertising materials, in addition to include it strongly in their positioning, as in the case of the winery
03 and 04 . In the case of winery 03 , because it has a small structure and little market share, it uses as a positioning and reports that it receives visits from consumers who come in search of the organic and see the other products better. In the case of winery 04 , the care with residues and the positioning of safe food, which goes beyond organic products, made it certified and adopted some practices for all products. In this sense, they hay a market positioning based on quality and safety of products.

In the case of winery 01 , its positioning is aimed at the large retail and the complete mix of products. This winery stopped producing and offering these products in 2016 due to the difficulties, besides not being tied to its market positioning. It reports production difficulties and certification, which made it unfeasible to provide the product because the organic wine produced today is not well perceived by its consumers. The winery 02 is positioned by cooperativism. Since its members are interested in organic production, due to their concern for their health, the cooperative needed to benefit the production of these. However, as the grape used has better acceptance for juice, the winery followed by this segment, as well as all the other wineries interviewed. This fact made the winery 02 the largest producer of organic grape juice in Brazil, which produces more than 300 thousand liters in 2015 , organic wine is not representative and it is marketed only supermarkets in the State of Rio Grande do Sul, Brazil.

On the other hand, the IBRAVIN representative says that it is still difficult to produce grapes organically due to climatic issues and lack of specific techniques, but there are projects to develop cultivars and appropriate techniques. In addition, new producers are emerging and seeking collaboration, mainly with FECOVINHO - Rio Grande do Sul Wine Cooperatives Federation and EMBRAPA Uva e Vinho - Brazilian Agricultural Research Corporation - Grape and Wine.

In an interview with the market intermediary, the interviewee shows that today the consumer, for the most part, still does not know the organic wine. For him, the important thing is that the product is the most sustainable possible and that from the first contact with this type of product, it will search for new, whether biodynamic, organic or natural. In addition, consumers today perceive as a poor quality product with poor communication quality, either because they present little information on labels and on websites, or because they are not accessible, by price or availability.

\subsection{Future outlooks}

Following the current scenario, the interviewees presented proposals for organic wine to gain space in this segment. An intermediate product, between the conventional and the organic wine, but certified, would serve the current market of organic wine, provided that it has a treatment with less waste and include in its production more sustainable processes.

In this sense, the sector presents programs that are being developed to make this possible.It is being implemented in the Brazilian wine sector actions such as Integrated Grape Production for Processing (PIUP, abbreviation in Portuguese), which enables the food production with safe, quality and the traceability of 
Table 1. Current view of the Brazilian wine sector.

\begin{tabular}{|c|c|}
\hline Availability of information & $\begin{array}{l}\text { Website, digital social networks, search engine, commercial representatives, advertising materials, } \\
\text { health professionals and points of sale. }\end{array}$ \\
\hline Actual production & $\begin{array}{l}\text { Few producers, few commercial production of organic wine, most are still in conversion, or are } \\
\text { doing sustainable work in wine, in the chain, less chemical intervention, tending to the natural. } \\
\text { Little certified product. Lack of methodology, technology for the production of fine wines. There are } \\
\text { experiments, but few products, is a field to develop. It represents little for the wineries, some } 3 \text { to } 5 \% \text {, } \\
\text { the one that represents more (winery } 03 \text { ), and } 1 \% \text { for the winery } 01 \text {. }\end{array}$ \\
\hline Challenges & $\begin{array}{l}\text { Producing grapes in an organic way due to climatic adversities, better management of the } \\
\text { vineyard, demand more work, labor, greater risk, needs better remuneration. Serra Gaúcha is the } \\
\text { biggest producer of wines, but it is not propitious to the organic ones due to the climatic adversities. }\end{array}$ \\
\hline Product demand & $\begin{array}{l}\text { Natural wine is best known to consumers, for which there is already a demand. When the consumer } \\
\text { taste the organic wine he look for other wines, whether natural, organic, biodynamic, sustainable } \\
\text { wines. (Note: importance of the intermediary in communicating the value of the product to the } \\
\text { consumer, since it presents and teaches what the product is and the difference between them). }\end{array}$ \\
\hline Trust and communication & Organic label. \\
\hline Definition & $\begin{array}{l}\text { There is still a lot of confusion in the conception (of what is organic wine), even for professionals } \\
\text { in the area, who sometimes confuse the terminology, even the use of "nature" for sparkling wine, } \\
\text { which has no connection with intervention in grape production, but rather in not using sugar } \\
\text { for the expedition liquor. }\end{array}$ \\
\hline Availability & Supermarkets, specialized stores, large retail. \\
\hline $\begin{array}{l}\text { Packaging, communication } \\
\text { and marketing }\end{array}$ & $\begin{array}{l}\text { Underdeveloped communication, there is usually no communication, website that gives access } \\
\text { to these products, they enter or in the same approach of the conventional or gain a communication } \\
\text { very similar to organic in general, there being no differentiation of organic wine. Missing information } \\
\text { on labels, the site does not show information about that system. In the supermarkets the products are } \\
\text { next to the table wines and in some cases in the section of organic foods. }\end{array}$ \\
\hline Regulation & $\begin{array}{l}\text { High cost to certify, there is no specific legislation for organic wine, only for organic grape and } \\
\text { processed organic food. }\end{array}$ \\
\hline Market & $\begin{array}{l}\text { The consumer still does not identify the product properly, he has difficulty in differentiating the } \\
\text { products of the wine in general, in addition, the cost of production is high, soon the product reaches } \\
\text { the most expensive consumer. It brought visibility to the other products of the winery. }\end{array}$ \\
\hline $\begin{array}{l}\text { What consumers are } \\
\text { looking for }\end{array}$ & $\begin{array}{l}\text { They look for the product because it is more sustainable, that has the face of Brazil, not because } \\
\text { it is organic, biodynamic or natural. They seek quality of life, do not have pesticides, health, have } \\
\text { no chemicals, do not affect the environment, health, quality of life and sustainability. }\end{array}$ \\
\hline Objectives of production & $\begin{array}{l}\text { Meet the demand of the segment, niche market, which is still little explored. Sustainability of the } \\
\text { business, mainly for the production of organic grapes and the quality of life that brings grape } \\
\text { producers. Health, well-being, quality of life of the cooperative members (in the case of the } \\
\text { cooperative), business opportunity. Aggregation of sustainable value for the brand of the winery } \\
\text { and its other products. A genuine product, without transgenic, purer, more natural, because it } \\
\text { is a world trend. Offer a quality product to the consumer. }\end{array}$ \\
\hline Other values & $\begin{array}{l}\text { ISO } 22000 \text {, food safety, controls the use of agrochemical, even in conventional production, grace } \\
\text { period, to avoid waste. Rainwater reuse and recycling. Conservation of local diversity, such as } \\
\text { animals and water resources. }\end{array}$ \\
\hline Consumer profile & $\begin{array}{l}\text { Consumers of class A and B, mostly between } 28 \text { and } 50 \text { years, up to } 70 \text { years, few young people, } \\
\text { some consumers of class C. }\end{array}$ \\
\hline Public policies & $\begin{array}{l}\text { Program PAS (Safe Food Program), for grapes for processing, with training of producers to reduce } \\
\text { waste, with guarantee of food safety, without residues in the final product. }\end{array}$ \\
\hline Product & $\begin{array}{l}\text { The sanity of the grape changes the wine standard, final quality, even using NS220, with the } \\
\text { restrictions. The product is a result of the quality of the grape and the crop. }\end{array}$ \\
\hline
\end{tabular}

Source: Author.

the whole system, thus seeking the lowest possible environmental impact [19]. Another existing practice on the Brazilian wine industrie for the production of grapes for processing is the Safe Food Program (PAS, abbreviation in Portuguese), which aims to manage the risks and dangers of grape production and processing, ensure product quality and consumer-safe products [20].

Furthermore, in Table 2 it is possible to perceive that there is a collective effort and that shows the importance of the participation of the consumer in this process.

Therefore, consumers are willing to collaborate, which is seen by their participation in organizations, as organic consumer associations and cooperatives. These consumers seek to know better the origin, the company, the producers and the techniques used. It is necessary to provide quality information and easy access, as well as placing the product in adequate and well-marked places of purchase. Moreover, communication and product marketing approach has to follow strategies merged between wine and organic food, with labels designed for this specific product and to meet the information requested by consumers as organic wine is seen as a premium product.

Thus, consumers seeking a product that meets the social, environmental, issues that go beyond organic quality itself, which is the absence of synthetic additives. That is, they are not looking for an organic product in itself, but for practices that involve organic agriculture. 
Table 2. Future prospects for the production and consumption of Brazilian organic wine.

\begin{tabular}{|c|c|}
\hline Information access & $\begin{array}{l}\text { Work colleagues, organized groups, network of contacts; Internet, websites, groups in digital social } \\
\text { networks, web pages and portals; Public agents, technical assistance; Consumer networks, consumer } \\
\text { cooperative, direct from producer, visits, point of sale, label, advertising material; Events, news, } \\
\text { studies and health professionals. }\end{array}$ \\
\hline Production & $\begin{array}{l}\text { The tendency is to produce a product free of pesticides (Agrochemical), or to do within the limits, } \\
\text { in the most sustainable way possible; Future challenge of producing more economically way; New } \\
\text { producers are migrating to the organic, or more sustainable; The Region of the Campanha Gaúcha, } \\
\text { located on the south of the State of Rio Grande do Sul, presents good potential for the production of } \\
\text { organic wines, because it has sandy soils and lower humidity. }\end{array}$ \\
\hline Challenges & $\begin{array}{l}\text { Reach the consumer who is willing to pay a little more; Lack of research; EMBRAPA is developing } \\
\text { resistant varieties, such as powdery mildew, mold and other diseases of the vine. }\end{array}$ \\
\hline Product demand & $\begin{array}{l}\text { The Brazilian organic market is still starting in the wine segment. Is growing, consumers are looking } \\
\text { for a more sustainable product, not exactly organic or biodynamic. It is creating a niche. }\end{array}$ \\
\hline Trust and communication & $\begin{array}{l}\text { Consumers trust on certification by audit, because the analysis process, participatory certification, } \\
\text { consumer participation and producer networks, knowing who produces, direct contact, product being } \\
\text { at the fair and being able to talk to the producer, information on the label, product design, people who } \\
\text { sell, produce, their networks of contacts, know the origin of the product, the production processes } \\
\text { and the organic label. }\end{array}$ \\
\hline Availability & $\begin{array}{l}\text { Direct from producer, ecological fairs, consumer cooperatives, local commerce and supermarkets, } \\
\text { specialty shops and organic food restaurants. }\end{array}$ \\
\hline $\begin{array}{l}\text { Packaging, } \\
\text { communication } \\
\text { and marketing }\end{array}$ & $\begin{array}{l}\text { It lacks an approach, good communication, good visual, it is necessary to qualify and sophisticate the } \\
\text { product communication. The consumer cooperative transmits these demands to producers, since the } \\
\text { group of consumers can achieve this approximation. It needs to have wine packaging, well presented, } \\
\text { with process information, who produces, quality, raw material. Sometimes you have a good product } \\
\text { but have not advanced in packaging, availability, scale, regularity in the market, product standard, } \\
\text { so you have to establish regularity and constant information. }\end{array}$ \\
\hline $\begin{array}{l}\text { What consumers } \\
\text { are looking for }\end{array}$ & $\begin{array}{l}\text { For being sustainable, diversification of production, environmental issue and respect for nature, } \\
\text { thinking about future generations, motivate this production, for being a real food, healthy, natural, } \\
\text { with special flavor, without chemical additives, pesticide residues and other waste. }\end{array}$ \\
\hline Other values & $\begin{array}{l}\text { Approach all sustainability actions, in addition to the minimum to organic production } \\
\text { certification, in the advertising discourse, since consumers take this information into account to } \\
\text { decide on a product**. }\end{array}$ \\
\hline Public policies & $\begin{array}{l}\text { MAPA's*** Project, published by EMBRAPA, which developed the Integrated Grapes Production } \\
\text { for Processing (PIUP), which are within the limits of resource use and agrochemicals. Developing } \\
\text { methodology, in addition to dissemination, development and certification, so that it avoids the } \\
\text { increase of costs and can add value to the final product. }\end{array}$ \\
\hline Product & $\begin{array}{l}\text { Thermovinification, which eliminates oxidative enzymes, may be the solution for further } \\
\text { standardization of the product. }\end{array}$ \\
\hline
\end{tabular}

* The framework addresses the vision of the sector, as actions to be able to supply organic wine, is included the sector and the wineries, in italics the vision of the consumers. ** Suggested by the author from the response of consumers. ***Brazilian Ministry of Agriculture, Livestock and Supply.

Source: Author.

\section{Conclusion}

It is possible to conclude that production efforts are moving in the sense of meeting consumer demand, but more integration between producers is needed to find methodologies for this crop. On the other hand, it is necessary to think in a specific segment of organic wine, a product positioning between wine and organic food. In this same sense, an intermediate product could meet the current demand of consumers, for a product that has sustainable guidelines and some organic-related practices in order to overcome production difficulties and thus, the wineries can meet the demand for a product with the minimum of possible residues and low production impact, such as a sustainable wine, with some certification process of sustainability.

Moreover, public policies would be important to encourage this production, rethinking value and tax incentives to producers. Regarding the market, it is necessary to rethink the approach, aligning the discourse and practice with what the consumer expects, sufficient and accessible information, a product of quality, availability and regularity in production. Companies also need to open up more to consumers, let them participate in the company, with access to information, making transparent the difficulties faced in providing this product and the benefits it brings.

Finally, as an exploratory research requires new research with a more conclusive focus, based on a more solid database, with a larger base of Brazilians consumers of natural, organic or sustainable wine. But it is still necessary that the market consolidates better, since there is still a small supply, and it is not possible to establish a specific profile of this consumer.

This research was financed with a scholarship by the Coordination for the Improvement of Higher Education Personnel - CAPES, an agency of the Brazilian Government.

\section{References}

[1] Á. M. Ritter, M. Borchardt, G. L. R. Vaccaro, G. M. Pereira, and F. Almeida, "Motivations for promoting the consumption of green products in an emerging country: Exploring attitudes of Brazilian consumers," J. Clean. Prod. 106, 507-520 (2015) 
[2] A. N. Almeida, C. Bragagnolo, and A. L. S. Chagas, "A Demanda por Vinho no Brasil: elasticidades no consumo das famílias e," Rev. Econ. e Sociol. Rural 53(3), 433-454 (2015)

[3] L. M. R. de Mello, "Tendência de Consumo e Perspectivas do Mercado de Vinhos no Brasil," in SIMPÓSIO NACIONAL DE FERMENTAÇÕES, p. 7 (2003)

[4] B. Chekima, S. Azizi Wafa Syed Khalid Wafa, O. Aisat Igau, S. Chekima, and S. Laison Sondoh Jr, "Examining green consumerism motivational drivers: does premium price and demographics matter to green purchasing?," J. Clean. Prod. 112, 3436-3450 (2016)

[5] SEBRAE, "O mercado para os produtos orgânicos está aquecido," Agronegócio. (2015). [Online]. Available: https://www.sebrae.com.br/sites/ PortalSebrae/artigos/o-mercado-para-osprodutos-organicos-esta-aquecido, 5f48897d3f94e410VgnVCM1000003b74010aRCRD [Accessed: 03-Feb-2017]

[6] J. F. da S. Protas, U. A. Camargo, and L. M. R. de Melo, "A vitivinicultura brasileira: realidade e perspectivas," Embrapa Uva e Vinho. (2002). [Online]. Available: http://www.cnpuv.embrapa.br/ publica/artigos/vitivinicultura/ [Accessed: 07-Mar-2017]

[7] J. P. Reganold and J. M. Wachter, "Organic agriculture in the twenty-first century," Nat. Plants 2(February), 1-8 (2016)

[8] M. Laureati, D. Jabes, V. Russo, and E. Pagliarini, "Sustainability and organic production: How information influences consumer's expectation and preference for yogurt," Food Qual. Prefer. 30(1), 1-8 (2013)

[9] F. Humbert, «Europe: la naissance douloureuse du vin «bio»», La Revue du Vin de France. (2012). [Online]. Available: http://www.larvf.com/, vins-bio-ue-commission-europeennereglementation-bruxelles-nicolas-jolygerard-bertrand-olivier-humbrecht, 13182, 4248636. asp [Accessed: 10-Mar-2017]

[10] D. Wilson, "Flavoured Wine - Fad, Fashion or Trend?," BIO Web Conf. 7, 3008 (2016)
[11] L. Chan, "Natural Wine Is The Hottest Trend In Winemaking Right Now: Here's Everything You Need To Know," Tech Times (2016). [Online] Available: http://www.techtimes . com/articles/133381/20160213/naturalwine-is-the-hottest-trend-in-winemakingright-now-here-s-everything-you-need-toknow.htm [Accessed: 10-Mar-2017]

[12] BRASIL, "LEI N. 10.831 - DE 23 DE DEZEMBRO DE 2003. Que dispõe sobre a agricultura orgânica e dá outras providências" (2003) [Online]. Available: http://www.planalto.gov.br/ccivil_03/leis/ 2003/L10.831.htm [Accessed: 04-Sep-2016]

[13] BRASIL, "INSTRUÇÃO NORMATIVA CONJUNTA N ${ }^{\circ} 18$, DE 28 DE MAIO DE 2009, Que regulamenta o processamento, armazenamento e transporte de produtos orgânicos," Diário oficial da União. (2009) [Online]. Available: http://www . inmetro.gov.br/barreirastecnicas/ponto focal . . \% 5Cpontofocal $\% 5$ Ctextos $\% 5$ Cregulam entos\%5CBRA_342.pdf [Accessed: 05-May-2017]

[14] L. Lockshin and A. M. Corsi, "Consumer behaviour for wine 2.0: A review since 2003 and future directions," Wine Econ. Policy, 1(1), 2-23 (2012)

[15] S. Mann, A. Ferjani, and L. Reissig, "What matters to consumers of organic wine?," Br. Food J. 114(2), 272-284 (2012)

[16] IPSOS-SUDVINBIO, «Les européens et le vin bio. chiffres et tendances», Montpellier (2015)

[17] IPSOS-SUDVINBIO, "Viticulture bio: une filière en pleine croissance," Lattes (2014)

[18] Agencebio, «Croissance Historique de la bio en france le secteur confirme son envol en 2016», Dossier de presse (2016) [Online]. Available: http://www . agencebio.org/sites/default/ files/upload/dp_bio_conf_septembre_ 200916.pdf [Accessed: 09-Jun-2017]

[19] S. V. da Silveira, L. da R. Garrido, and A. Hoffmann, Produção integrada de uva para processamento: bases para a adoção da produção integrada, 1st ed. Brasília: Embrapa (2015)

[20] IBRAVIN, "PAS: Garantia de qualidade do campo à mesa," Informativo Saca-rolhas, Bento Gonçalves, p. 16 (2013) 